\title{
Development of Creativity Based Literation Management Model in Junior High Schools (SMPN) Payakumbuh City
}

\author{
Dasril, Rusdinal, Yahya
}

\begin{abstract}
This research paper was written against the background that the implementation of literacy activities at Payakumbuh City has not been running effectively and efficiently. Several technical and practical problems faced by school principals. The habit of reading 15 minutes at school has not been implemented well, because there is no literacy management model. For this reason, the authors have developed a creativity-based literacy management model as a solution to existing problems. This research and development design uses the Borg and Gall model which consists of ten stages which are constructed into four steps, i.e; preliminary studies, development, field testing and dissemination. The research subjects were the principal of junior high schools, Indonesian language teachers and library managers in Payakumbuh City. Data were collected through interviews, observations, questionnaires, and validation sheets. Quantitative data were processed using SPSS 20 and reduced qualitative data as suggested by Mattew and Huberman. The model validity obtained a mean of 4.53 with a very valid interpretation. The practicality level of the product was obtained by an average of 4.13 with $83.09 \%$, which means that the literacy management model developed is practically used. Meanwhile, the effectiveness test reached 85.19 which means effective. Furthermore, the difference between the pre-test and post-test results obtained 32.13 points, this means that there is an increase in the principal's ability to manage management.
\end{abstract}

Keywords: development, management, literacy, creativity

\section{INTRODUCTION}

Developed countries in education begin in literacy culture. As one of the great nations, Indonesia must be able to develop a culture of literacy as a requirement for life skills in the 21st century through integrated education, starting from family, school, to society. The reading and writing habits of students in Indonesia are still low [1]. This is evidenced by the data from the Program for International Student Assessment which is abbreviated as PISA in 2011 regarding the low reading interest of elementary school students where Indonesia is ranked 42 out of 45 countries, while in 2018

Manuscript received on February 08, 2021.

Revised Manuscript received on March 30, 2021.

Manuscript published on March 30, 2021.

* Correspondence Author

Dasril*, Doctoral Student of Education administration, Universitas Negeri Padang - Indonesia. Email: dasrilmpd123@gmail.com

Rusdinal, Senior lecturers/professors of Education administration, Universitas Negeri Padang - Indonesia: rusdinal@fip.unp.ac.id

Yahya, Senior lecturers/professors of Education administration, Universitas Negeri Padang - Indonesia. Email: yahya@fbs.unp.ac.id

(C) The Authors. Published by Blue Eyes Intelligence Engineering and Sciences Publication (BEIESP). This is an open access article under the CC BY-NC-ND license (http://creativecommons.org/licenses/by-nc-nd/4.0/) based on PISA data Indonesia was ranked 74th out of 76 countries $[1,2]$. For that, school literacy programs need to be developed. The role of the principal in the success of literacy in schools is very important [3], especially in planning, programming, budgeting, organizing, supervising, motivating and evaluating literacy programs [4]. The success of the School Literacy Movement (GLS) depends on how the principal manages, administers and manages the school literacy program he leads [5]. Budget is how principals develop school through libraries that support literacy development [5]. Organizing is how principals organize all the components, parts, and the respective positions of teachers and education personnel [6]. Implementation (actuating) that is how the principal carries out or move throughout the business, how, techniques, and methods to encourage the school community to be willing and sincere to work with the best to achieve the goal of literacy [7]. controlling i.e how the principal supervises literacy activities. The purpose of supervision carried out by the principal is to monitor the process of activities, facilities and infrastructure and find solutions if they encounter obstacles [8].

The evaluation which is to see what are the weaknesses and strengths of the literacy program has been implemented and can understand what the challenges and opportunities of literacy movements. Evaluation activities start from planning activities to monitoring school literacy [9]. Literacy is a person's ability to understand, understand and process information into a learning resource [10]. So it can be concluded that literacy is more than just reading writing, but the ability of a person to develop the potential and ability to analyze and compare all sources of information in making decisions [11]. There are six types of literacy programs, i.e: reading and writing literacy, numeric literacy, scientific literacy, financial literacy, digital literacy, cultural literacy and citizenship [12]. To increase students' interest in reading in educational settings, the government issued a Regulation of the Minister of Education and Culture Number 23/2015. One of the activities in the movement is activity 15 minutes of reading non-lesson books before learning time begins. By requiring and giving students time to read books every day for 15 minutes, either before starting class hours, in the middle of learning or at the end of learning [13].

Based on the results of the author's observations on the implementation of literacy specifically in (SMP) in Payakumbuh City, it turns out that the literacy program in each school is still ineffective.

Published By:

Blue Eyes Intelligence Engineering

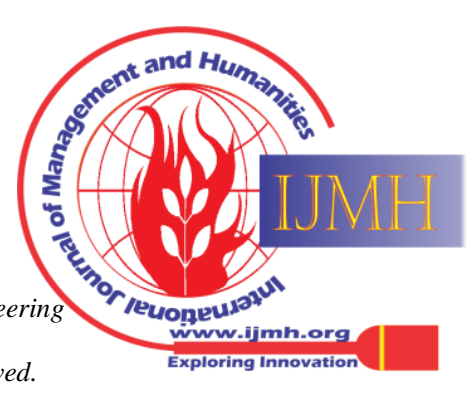


This statement is supported by the results of [14] research at the IT Insan Harapan junior high school, South Tangerang, which states that literacy implementation is still implemented less regularly.

\section{METHODS}

The research used was development research (Research \& Development). Development research begins by analyzing the theory of management functions and their implications for creativity-based literacy. The research and development steps used in this study consist of 10 (ten) steps developed by [15], among others:

Table-I: Research procedures

\begin{tabular}{|l|l|}
\hline No & \multicolumn{1}{|c|}{ Research Procedures } \\
\hline 1 & Research and information collection \\
2 & Planning \\
3 & Develop preliminary form a product \\
4 & Preliminary field testing \\
5 & Main product \\
6 & Main field testing \\
7 & Operational product revision \\
8 & Operational field testing \\
9 & Final product revision \\
10 & Dissemination and implementation \\
\hline
\end{tabular}

Source: [15]

\section{A. Research}

Instruments used in this study were of two types, i.e data collection instruments and product validation instruments. Data collection instruments include: 1) needs analysis instruments, i.e; a) observation guidelines, b) interview guidelines and c) questionnaires., 2) practicality test instruments: a) literacy management guidance instruments, b) syntax implementation instruments, c) literacy management supplement instruments, 3) effectiveness test instruments: a) Cognitive test instruments, b) affective test instruments, and c) psychomotor test instruments.

While the instrument for validating the instrument and the product consists of four parts, i.e: 1) the instrument to validate the needs analysis, 2) the instrument to validate the product, 3) the instrument to validate the practicality, and 4) the effectiveness.

\section{B. Data analysis techniques data}

Analysis techniques in this study consisted of 6 (six) analyzes, where the data analyzed consisted of 4 (four) parts, including analysis of literacy management needs, analysis of the results of validity, practicality, and effectiveness. Described as follows:

1. Descriptive analysis, which describes the results of the analysis of needs, validity, practicality and effectiveness which includes: mean, and percentage.

2. Aiken's V analysis [16], is used to analyze the results of the instrument validity test and product validity with the formula:

$$
\mathrm{V}=\sum s[n(c-1
$$

Information:

$\mathrm{s}=\mathrm{r}-\mathrm{lo}$

lo = lowest validation score

$\mathrm{c}=$ lowest validation score

$\mathrm{r}=$ number given by assessors

$\mathrm{n}=$ number of expert assessors

3. Inter-rater correlation analysis (intraclass correlation

Retrieval Number:100.1/ijmh.F1236025621

DOI:10.35940/ijmh.F1236.035721

Journal Website: www.ijmh.org coefficient) using SPSS version 20 IMB is used in making decisions on the results of one validator's assessment with another [17].

4. Alpha Cronbach analysis using SPSS version 20 IMB, is used to test the internal reliability of the instrument.

5. Analysis of the difference in the mean practicality score was carried out to determine the practicality level of the literacy management model based on the observations and assessments of users of the literacy management model. Practical data were analyzed by looking for means and percentages [17] with the following formula:

$$
\begin{gathered}
S A=\frac{P S}{S M I} x ! \\
S A=\frac{P S}{S M I} \times 100 \%
\end{gathered}
$$

Information:

$$
\begin{array}{ll}
\text { SA } & =\text { Final Score } \\
\text { PS } & =\text { Acquisition of } \\
\text { SMI Score } & =\text { Maximum Ideal Score } \\
\text { SP } & =\text { Rating Scale }
\end{array}
$$

The criteria for practicality testing are based on the average ratings of experts which can be described in the following Table-II below:

Table-II: Criteria for practicality test

\begin{tabular}{|c|l|l|}
\hline No & \multicolumn{1}{|c|}{ Score Range } & \multicolumn{1}{|c|}{ Interpretation } \\
\hline 1 & $>4.20$ & Very Practical \\
2 & $>3.40-4.20$ & Practical \\
3 & $>2.60-3.40$ & Quite Practical \\
4 & $>1.80-2.60$ & Less Practical \\
5 & $\leq 1,80$ & Not Practical \\
\hline
\end{tabular}

Source: [17]

6. Paired t-test analysis using SPSS, to measure the level of effectiveness of literacy management implementation, by comparing the pre-test and post-test results after being given treatment on understanding literacy management. The prerequisite for testing the data is that the prerequisite test is carried out, i.e the data must come from normally distributed and homogeneous data [17].

7. Research Hypothesis to find out whether the increase in the average value is performed a two-sample difference test paired with the following hypothesis.

$\mathrm{H}_{0}$ : the pre-test average value is the same as the post-test average

$\mathrm{H}_{\mathrm{i}}$ : there is a significant difference between the pre-test mean value and the post-test mean score Pre-test

8. Analysis of the difference between the test and Post-test [18] using the following formula: Information:

$\begin{array}{lllll} & & \begin{array}{l}\mathrm{O}_{1}=\text { pre-test value (before being given } \\ \text { treatment) } \\ \mathrm{O}_{2}=\text { post-test value (after being treated } \\ \text { Effect of treatment on literacy management } \\ =(\mathrm{O} 2 \text { - O1) }\end{array}\end{array}$

Published By:

Blue Eyes Intelligence Engineerin

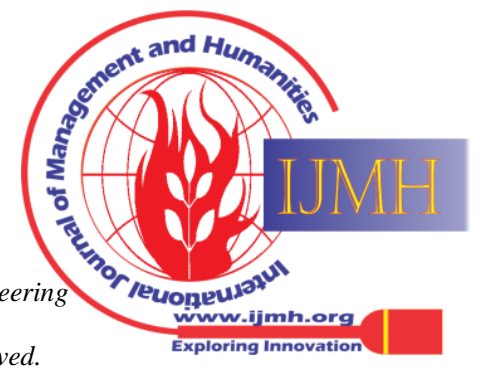




\section{REVIEW CRITERIA}

At this stage the results of the preliminary phase of research will be presented, starting from instrument validation by the three validators consisting of content experts, linguists and graphic experts The purpose of validation is to determine whether the instrument that has been prepared can measure what should be measured in creativity-based literacy management development research [19]. The reliability test of instrument items is presented in the following Table-III below:

Table-III: Results of the validity and reliability of the instrument

\begin{tabular}{|c|c|c|c|c|c|c|c|}
\hline No & & Instrument & Average & Aiken'V & ICC & Cronbach's Alpha Coefficient & Interpretation \\
\hline \multirow{3}{*}{1} & \multirow{3}{*}{ Needs Analysis } & interview guidelines & 4.79 & 0.94 & 0.714 & 0.952 & Valid \\
\hline & & Observation guide & 4.71 & 0.93 & 0.857 & 0.980 & Valid \\
\hline & & Questionnaire & 4.75 & 0.94 & 0.714 & 0.952 & Valid \\
\hline \multirow{3}{*}{2} & \multirow{3}{*}{ Product Validation } & Model Book & 4.75 & 0.94 & 0.857 & 0.980 & Valid \\
\hline & & Principal's Guide & 4.67 & 0.92 & 1.000 & 1.000 & Valid \\
\hline & & Literacy Materials & 4.71 & 0.93 & 0.857 & 0.980 & Valid \\
\hline \multirow{4}{*}{3} & \multirow{4}{*}{ Practicality } & Guidelines for implementing literacy & 4.75 & 0.94 & 0.714 & 0.952 & Valid \\
\hline & & Syntax execution & 4.71 & 0.93 & 0.857 & 0.980 & Valid \\
\hline & & Learning supplement & 4.71 & 0.93 & 0.625 & 0.930 & Valid \\
\hline & & Competency Test Sheet & 4.75 & 0.94 & 0.714 & 0.952 & Valid \\
\hline & & Average & 4.73 & 0.934 & 0.791 & 0.966 & Valid \\
\hline
\end{tabular}

Based on Table-III above, information can be obtained that based on the results of Aiken $\mathrm{V}$ analysis with a rater consisting of 3 people, the mean value is 473 , the mean value of Vhtg (0.934)> Vtbl (0.92), because Aiken's V value is greater than Vtbl, it can be concluded that all instruments in this study are declared valid, while the results of the reliability analysis based on the coefficient Cronbach Alpha obtained a mean of Rhtg (0.966)>Rtbl (0.92), this indicates that all instruments in this study were reliable, while the results of the intra-class coefficient analysis were 0.791 , this shows that the three validators in assessing the instrument are consistent with each other. After the instrument was declared valid, the next step was to carry out the preliminary phase of research by interviewing teachers, observing the implementation of school literacy and distributing questionnaires to teachers and students. Preliminary observations can be presented as follows:

\section{A. Observations}

Observation data was conducted to obtain direct information on the implementation of literacy in schools, the results of data analysis can be described as Tabel-IV follows.

Table-IV: Results of literacy observations

\begin{tabular}{|c|l|c|c|}
\hline No & \multicolumn{1}{|c|}{ Aspect Rate } & Average & Achievement \% \\
\hline 1 & Habituation & $2: 03$ & 50.71 \\
2 & Creativity & $2: 49$ & 62.14 \\
3 & Fisilitas GLS & 2.83 & 70.83 \\
4 & Commitment & 2.27 & 56.79 \\
5 & Literacy Management & 2.14 & 53.50 \\
\hline \multicolumn{2}{|l|}{ Average } & 2.35 & 58.80 \\
\hline
\end{tabular}

Based on Table-IV above, it can provide information that the implementation of literacy in schools before training and assistance in literacy management was obtained by an overall mean of 2.35 with $58.80 \%$ of the 5 assessment aspects. This means that the implementation of literacy so far in SMP in Payakumbuh has been running and implemented in schools, but the implementation is not optimal, it still requires training and assistance, especially in managing literacy by school principals.

\section{B. Interview results}

The results of interviews with teachers and students about the implementation of literacy so far at Payakumbuh Public Middle School, among others: 1) in general, the teachers said that the implementation of literacy was not optimal, this was motivated by the principal in managing literacy not fully committed. Socialization of the literacy movement in schools has been carried out, but over time the enthusiasm for reading books has disappeared; 2) The principal does not understand how to manage literacy so that the implementation of literacy does not go as expected; and 3) Supporting facilities for the implementation of literacy is very minimal so that school residents are less motivated.

\section{Results of questionnaire distribution}

The results of data analysis on literacy implementation can be seen in the following Table-V below:

Table-V: Results of literacy management needs analysis

\begin{tabular}{|c|c|c|c|c|c|c|c|c|c|c|c|c|c|c|}
\hline \multirow{2}{*}{$\begin{array}{c}\text { Assessment } \\
\text { Aspects }\end{array}$} & \multirow{2}{*}{ Indicator } & \multirow{2}{*}{ Items } & \multicolumn{2}{|c|}{ (5) } & \multicolumn{2}{|c|}{ (4) } & \multicolumn{2}{|c|}{ (3) } & \multicolumn{2}{|c|}{ (2) } & \multicolumn{2}{|c|}{ (1) } & \multirow[t]{2}{*}{ Score } & \multirow[t]{2}{*}{$(\%)$} \\
\hline & & & $\mathbf{F}$ & $\%$ & $\mathbf{F}$ & $\%$ & $\mathbf{F}$ & $\%$ & $\mathbf{F}$ & $\%$ & $\mathbf{F}$ & $\%$ & & \\
\hline \multirow{4}{*}{$\begin{array}{l}\text { Literacy } \\
\text { Management }\end{array}$} & Planning & 7 & 120 & 85.71 & 16 & 0.93 & 4 & 2.86 & 0 & 0.00 & 0 & 0.00 & 4.83 & 96.57 \\
\hline & Program & 2 & 14 & 35.00 & 19 & 2.71 & 1.00 & 2.50 & 1 & 2.50 & 4 & 10.00 & 3.98 & 77.50 \\
\hline & Organizing & 2 & 19 & 47.50 & 0 & 0.00 & 1 & 2.50 & 10 & 25.00 & 10 & 25.00 & 3.20 & 64.00 \\
\hline & Motivation & 2 & 20 & 50.00 & 0 & 0.00 & 1 & 2.50 & 9 & 22.50 & 10 & 25.00 & 3.28 & 65.50 \\
\hline
\end{tabular}

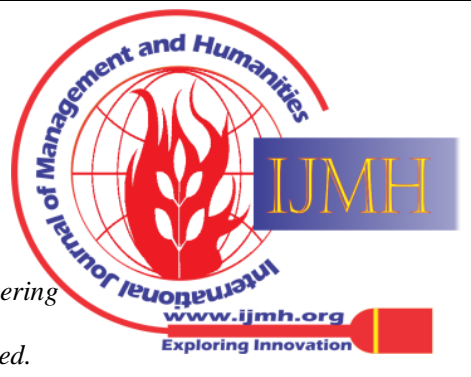




\begin{tabular}{|c|c|c|c|c|c|c|c|c|c|c|c|c|c|c|}
\hline & Supervision & 2 & 39 & 97.50 & 1 & 0.05 & 0 & 0.00 & 0 & 0.00 & 0 & 0.00 & 4.98 & 99.50 \\
\hline & Evaluation & 3 & 57 & 95.00 & 3 & 0.16 & 0 & 0.00 & 0 & 0.00 & 0 & 0.00 & 4.95 & 99.00 \\
\hline & & 23 & 302 & 63.39 & 46 & 0.70 & 7 & 1.48 & 46 & 10.86 & 58 & 13.43 & 4.00 & 79.70 \\
\hline Literacy & Habit & 4 & 30 & 37.50 & 10 & 1.33 & 2 & 2.50 & 18 & 22.50 & 20 & 25.00 & 3.15 & 63.00 \\
\hline & Development & 2 & 14 & 35.00 & 22 & 0.00 & 4 & 10.00 & 0 & 0.00 & 0 & 0.00 & 4.25 & 85.00 \\
\hline & & 6 & 44 & 36.25 & 32 & 4.41 & 6 & 6.25 & 18 & 11.25 & 20 & 12.50 & 3.70 & 74.00 \\
\hline GLS facilities & Library & 3 & 0 & 0.00 & 0 & 0.00 & 0 & 0.00 & 0 & 0.00 & 0 & 0.00 & 1.13 & 0.00 \\
\hline & Classroom corner & 2 & 7 & 17.50 & 13 & 0.00 & 0 & 0.00 & 34 & 85.00 & 16 & 40.00 & 3.33 & 85.50 \\
\hline & & 5 & 7 & 8.75 & 13 & 0.00 & $\mathbf{0}$ & 0.00 & 34 & 42.50 & 16 & 20.00 & 2.23 & 42.75 \\
\hline
\end{tabular}

Based on the results of the Shapiro-Wilk normality test above, the sig (p) value is obtained. pre-test of 0.482 and the value of sig. post-test of 0.151 , because of the sig. pre-test and post-test $(\mathrm{p})>0.05$, it can be concluded that the data from the pre-test and post-test results in this study came from normally distributed data. Furthermore, the homogeneity test was carried out.

Table-VI: Results of Homogeneity

\section{Test of Homogeneity of Variances}

Results

\begin{tabular}{|c|c|c|c|}
\hline Levene Statistic & df1 & df2 & Sig. \\
\hline 1.264 & 1 & 28 & .270 \\
\hline
\end{tabular}

Based on the above homogeneity test with Levene analysis obtained sig. (p) of 0.270 , because of the sig. $(0.270)>0.05$, it can be concluded that the pre-test and post-test data came from homogeneous data. After the test data requirements meet the requirements, it can be continued to analyze the pre-test and post-test results with paired sample T-Test paired data. Visually, the difference in the effectiveness of the creativity-based literacy management model based on the pre-test and post-test results can be shown in the following Table-VII:

Table-VII: Results of the analysis of data descriptions pre-test and post-test

\begin{tabular}{|l|c|c|c|c|c|}
\hline & N & Minimum & Maximum & Mean & $\begin{array}{c}\text { Std. } \\
\text { Deviation }\end{array}$ \\
\hline Pre_Test & 15 & 40 & 68 & 53.53 & 7.873 \\
\hline Post_Test & 15 & 77 & 96 & 85.67 & 5.122 \\
\hline Gain Score & \multicolumn{5}{|l|}{} \\
\hline
\end{tabular}

Table-VII above provides information that the mean achievement pre-test was 53.53 with a standard deviation of 7,873 , while the mean acquisition post-test was 85.67 with a standard deviation of 5,122, based on the results. The pre-test and post-test obtained value of the difference (gains core) between the pre-test to post-test by 32.13 points, it can be concluded that the knowledge of the participants after the training had increased by 32.13 points.

Table- VIII: Attitude assessment results

\begin{tabular}{|c|c|c|c|c|}
\hline No & Participant Code & Average & Achievement (\%) & Information \\
\hline 1 & Participants 01 & 4.60 & 90.00 & Very Effective \\
\hline 2 & Participants 02 & 4.00 & 82.00 & Very Effective \\
\hline 3 & Participants 03 & 4.20 & 86.00 & Very Effective \\
\hline 4 & Participants 04 & 4.60 & 90.00 & Very Effective \\
\hline 5 & Participants 05 & 4.20 & 84.00 & Very Effective \\
\hline 6 & Participants 06 & 4.00 & 82.00 & Very Effective \\
\hline 7 & Participants 07 & 4.20 & 86.00 & Very Effective \\
\hline 8 & Participants 08 & 4.60 & 90.00 & Very Effective \\
\hline 9 & Participants 09 & 4.20 & 84.00 & Effective \\
\hline 10 & Participants 10 & 4.60 & 90.00 & Very Effective \\
\hline 11 & Participants 11 & 4.00 & 82.00 & Very Effective \\
\hline 12 & Participants 12 & 4.20 & 86.00 & VeryEffective \\
\hline 13 & Participants 13 & 4.60 & 90.00 & Very Effective \\
\hline 14 & Participants 14 & 4.20 & 84.00 & Very Effective \\
\hline 15 & Participants 15 & 4.00 & 82.00 & Very Effective \\
\hline \multicolumn{2}{|r|}{ Average } & 4.28 & 85.87 & Very Effective \\
\hline
\end{tabular}

Table-VIII above can provide information that out of 15 participants the average score of activity was 4.28 with an achievement level of $85.87 \%$, It can be concluded that during the training process the principal and Indonesian language teacher are active.

\section{Results of the Skills Assessment}

The level of the dimensions of the participant's skills in planning a literacy program according to the literacy management syntax can be presented as follows Tabel-IX below:

Table- IX: Skills assessment results

\begin{tabular}{|c|c|c|c|c|}
\hline No & Participant Code & Average & Achievement\% & Information \\
\hline 1 & Participants 01 & 4.35 & Mastered & 82.00 \\
\hline 2 & Participants 02 & 4.10 & 85.00 & Mastered \\
\hline 3 & Participants 03 & 4.25 & Mastered \\
\hline
\end{tabular}

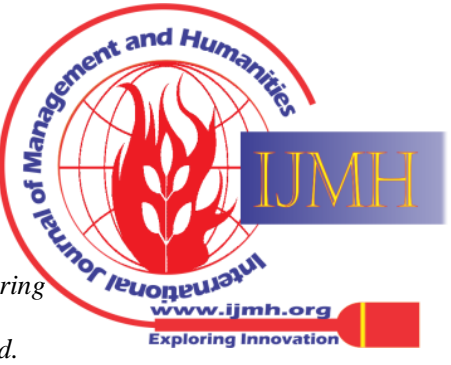




\begin{tabular}{|c|c|c|c|c|}
\hline 4 & Participants 04 & 4.30 & 86.00 & Mastered \\
\hline 5 & Participants 05 & 4.15 & 83.00 & Mastered \\
\hline 6 & Participants 06 & 4.10 & 82.00 & Mastered \\
\hline 7 & Participants 07 & 4.25 & 85.00 & Mastered \\
\hline 8 & Participants 08 & 4.35 & 87.00 & Mastered \\
\hline 9 & Participants 09 & 4.20 & 84.00 & Mastered \\
\hline 10 & Participants 10 & 4.35 & 87.00 & Mastered \\
\hline 11 & Participants 11 & 4.10 & 82.00 & Mastered \\
\hline 12 & Participants 12 & 4.25 & 85.00 & Mastered \\
\hline 13 & Participants 13 & 4.25 & 85.00 & Mastered \\
\hline 14 & Participants 14 & 4.15 & 83.00 & Mastered \\
\hline 15 & Participants 15 & 4.10 & 82.00 & Mastering \\
\hline \multicolumn{2}{|r|}{ Average } & 4.22 & 84.33 & Mastering \\
\hline
\end{tabular}

Based on the acquisition of data on the skill level of participants in preparing literacy programs in table 28 above, an average of 4.22 was obtained with an achievement level of $84.33 \%$, it can be concluded that the skill level of principals and Indonesian teachers increased with very effective interpretation. Furthermore, from the results of the cognitive, affective and psychomotor assessment above, then weighted to get the final score of the overall effectiveness of the model as in the following Table-X below.

Table-X: Recapitulation results of the model effectiveness assessment model

\begin{tabular}{|c|c|c|c|c|}
\hline No & Domain & Achievement (\%) & Weight (\%) & NA \\
\hline 1 & Cognitive & 85.67 & 30 & 25.70 \\
\hline 2 & Affective & 85.87 & 30 & 25.76 \\
\hline 3 & Psychomotor & 84.33 & 40 & 33.73 \\
\hline \multicolumn{3}{|c|}{ Average } & 100 & 85.19 \\
\hline
\end{tabular}

Based on Table-X above, it can be concluded that the effectiveness value is $85.19 \%$, it can be concluded that the literacy management model after being implemented to school principals and Indonesian teachers shows very effective results, seen from the results cognitive, attitude and psychomotor values. This means that the creativity-based literacy management model is very effective in increasing the ability of school principals to understand, plan and implement school literacy programs.

\section{E. Evaluation}

After the implementation of the model is done, then revise the management model of literacy and management guide literacy along with material literacy appropriate feedback and criticism from promoters, experts (validator) and practitioners, as well as the results of the final evaluation as follows: 1) Results in Revised Literacy Management Model: The revision of the literacy management model was carried out based on the suggestions of experts at the time of validation. The final results of model development can be seen in Figure 3 below which shows the components of the model from the philosophical foundation to the objectives of training for teachers in a comprehensive manner; and 2) Results of the Supporting Revision of the Model: The revision of the supporting model is not too much improvement, but part of the syntax is in the planning phase where before compiling a literacy program plan, a SWOT analysis should be carried out first about what are the strengths, weaknesses, opportunities and threats to the literacy program that will be implemented.

\section{DISCUSSION}

After all stages of research and development of the literacy management model were carried out, it was further revised based on input from the five experts and based on the results of field empirical tests to obtain the final creativity-based literacy management.

\section{A. The development process of a literacy management model-based}

The development process starts from the stage of analyzing the needs of school principals in implementing literacy. On the analysis of needs in the field, it provides a general description of the principal's ability to plan literacy programs is still less than what is expected according to PERMENDIKBUD number 23/2015. Based on the results of interviews and distribution of questionnaires to several school principals and Indonesian language teachers, it was stated that the implementation of literacy was only socializing, so this situation made school principals have no experience in planning literacy program activities. Furthermore, the researcher's own experience regarding the implementation of literacy in schools was not implemented optimally. Some schools have not carried out 15-minute reading activities at all.

\section{B. Validity, practicality and effectiveness}

Product Validation: A valid model is a model that has received observations and assessments from educational experts both from the elements of language, content and graphics (Kumar et al., 2019). Guidelines in deciding validation are based on the validity table criteria $(\mathrm{V})$ and the reliability criteria $(R)$. The decision-making criteria are based on the Aiken's $\mathrm{V}$ and tables $R$, i.e, $\mathrm{V}_{\mathrm{htg}}$ must be greater than $\mathrm{V}_{\mathrm{tbl}}$ according to the number of raters (rater) and the Likert scale used in the questionnaire [19-21] as well as matters in the reliability analysis.

Practicality: Model is said to be practical if it can provide convenience in implementing the literacy management model that has been developed. Furthermore, the literacy management model developed is said to be practical if it has received recognition from resource persons and school principals as users.

Published By:

Blue Eyes Intelligence Engineering DOI:10.35940/ijmh.F1236.035721

Journal Website: www.ijmh.org

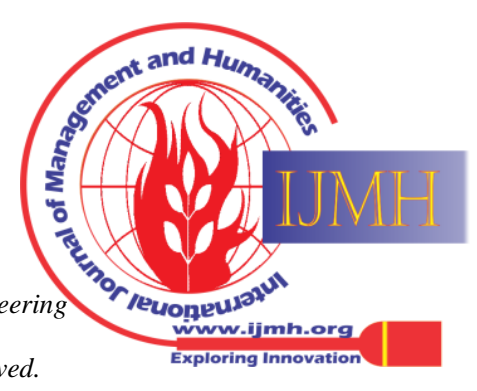


Furthermore, the practicality of a model is measured from; first, the ease of the implementation of literacy management instructions, the second the ease of the literacy management syntax, the third the ease of reading literacy material, the reading fourth these of the competency test sheet.

Effectiveness: The creativity-based literacy management model is obtained through 1) increasing the knowledge possessed by the principal after attending the training. the increase in knowledge referred to in this study is the results of the achievements obtained by the principal in understanding how to prepare literacy plans and programs through the pre-test, the implementation of which is tested before the chasing begins while the post-test is carried out after the learning is complete, 2) observing changes in the attitude of the head during the school following the learning process about literacy management, 3) assessing the skills of principals in planning and compiling literacy programs.

Based on the data analysis on the effectiveness of the management model, the pre-test means the score was 53.53, while the post-test mean score was 85.67 , so the gain score was 32.13 points. It can be concluded that the creativity-based literacy management model can improve the ability of school principals to plan and compile literacy programs. This statement is supported by the results of research suggesting that the effectiveness of the resulting model can be seen from the difference in scores between pre-test and post-test.

The effectiveness of the model is also seen from the change in the attitude of the principal during the learning process. Based on the results of the analysis of attitude change data, the mean value was 4.29 , with the achievement of $85.87 \%$. It can be concluded that the principal and Indonesian language teachers play an active role in participating in learning and show a positive attitude in understanding literacy management.

The effectiveness of the model is then seen from the principal's psychomotor ability in compiling and designing literacy programs after participating in literacy management learning, the average value is 4.23 , with the achievement of $84.69 \%$. This means that the skills of school principals in developing and designing literacy programs according to the needs of their respective schools have increased.

\section{CONCLUSION}

After conducting research and development of a creativity-based literacy management model at the Payakumbuh public junior high school implemented, it can be concluded that the process of developing and testing the validity, practicality and effectiveness of the model is as follows: 1) The development process starts from the needs analysis stage of literacy management in schools, then conduct a theoretical study of literacy management functions, and the abilities that must be mastered by the principal in compiling and designing literacy programs according to school needs, secondly designing a draft literacy management model based on the theoretical analysis of literacy management models and what competencies must be mastered. by the principal in planning, compiling and implementing literacy implementation in schools, resulting in a draft literacy management model as well as a draft guideline for school principals and literacy materials to support the model. develop literacy management models and school principal guidelines and literacy materials to produce a final model by the needs in planning, implementing and implementing creativity-based literacy management in junior high schools in Payakumbuh City; 2) The syntax of the literacy management model developed is based on the management functions proposed by experts and the basis for model development is developed based on the opinions of several management experts to produce a literacy management syntax consisting of seven phases, i.e; planning, programming, budgeting, organizing, motivation, monitoring and evaluation; 3) Results of validation, practicality and model effectiveness the model that has been developed in this study is declared valid based on the assessment of the five education experts, where the language, content and graphics of the resulting model have met the criteria that should exist in the model and can be counted on in improving abilities. principals in planning, implementing and evaluating literacy programs. Furthermore, the literacy management model that has been developed is stated to be practical and easy to use by resource persons and school principals as model users. The literacy management model is declared effective in increasing the ability of school principals to plan, implement and evaluate literacy programs. This can be seen from the results of the data analysis of the increase in knowledge, attitudes and psychomotor for the principal. Furthermore, the improvement of the literacy management model is based on suggestions and criticisms from the two promoters when carrying out guidance, proposal seminars, results seminars, and input from discussants and experts (validators) so that a final model is valid, practical and effective.

\section{REFERENCES}

1. S. Rejeki. Indonesia Membaca. Buletin Perpustakaan, 1(2), 2020, pp. 45-58.

2. A. Saputri, R. Susanti, A. Slamet. Development of Biological Science Literacy Questions Based on the PISA Framework. 4th Sriwijaya University Learning, 513, 2020, pp. 44-49.

3. R.M Bean, A.S Dagen, J. Ippolito, D. Kern. Principals' perspectives on the roles of specialized literacy professionals. Elementary School Journal, 119(2), 2018, pp. 327-350.

4. J.P. Milko. Improving Physical Literacy In Middle School Indigenous And Non-Indigenous Students. 2020.

5. B. Lian. The Influence of School Literacy Movement and Reading Habit on Student's Achievement. 20(1), 2020, pp. 144-155

6. F. Cao, W. Wu, B. Stvilia. Library makerspaces in China: A comparison of public, academic, and school libraries. Journal of Librarianship and Information Science, 52(4), 2020, pp. 1209-1223.

7. N.R. Stanger, N. Engelfried, S. Clement, A. Kunz, R. Grasso, E. S. Brine. Can We Teach the Earth Charter Anymore? A Critical Examination of the Earth Charter's Role in Education. Canadian Journal of Environmental Education (CJEE), 23(3), 2020, pp. 31-53.

8. N. Dempster, T. Townsend, G. Johnson, A. Bayetto, S. Lovett, E. Stevens. Leadership and literacy: Principals, partnerships and pathways to improvement. Springer. 2017.

9. Ö. Ece Demir-Lira, L.R. Applebaum, S. Goldin-Meadow, S.C. Levine. Parents' early book reading to children: Relation to children's later language and literacy outcomes controlling for other parent language input. Developmental Science, 22(3), 2019, pp. e12764.

10. A. Ayeni. Principals' decision-making strategies and teachers productivity in secondary schools in Ondo central Senatorial 1 District. Double Blind Peer Reviewed International Research Journal, 18(10), 2018, pp. 1-13.

Published By:

Blue Eyes Intelligence Engineering

\& Sciences Publication

(C) Copyright: All rights reserved.

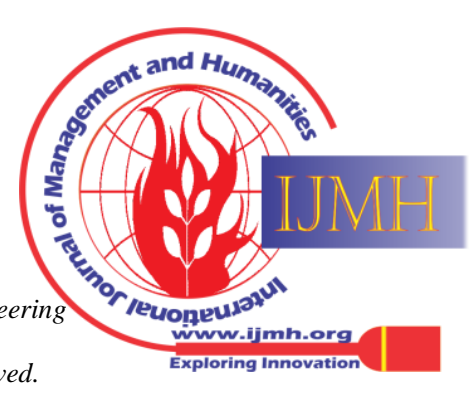


11. T.K. Yu, M.L. Lin, Y.K. Liao. Understanding factors influencing information communication technology adoption behavior: The moderators of information literacy and digital skills. Computers in Human Behavior, 71, 2017, pp. 196-208.

12. A. Velicanu, I. Lungu, V. Diaconita, C. Nisioiu. The 9 th Internationa Scientific Conference eLearning and software for Education. 380-386. 2013.

13. B.A. O'Brien, N.A. Arshad. The structure of home literacy environment and its relation to emergent English literacy skills in the multilingual context of Singapore. Early Childhood Research Quarterly, 53, 2020, pp. 441-452.

14. Kemendikbud. Peraturan Menteri Pendidikan dan Kebudayaan Republik Indonesia. 2015.

15. A. Widodo. Implementasi Program Gerakan Literasi Sekolah di Sekolah Menengah Pertama (SMP). Tarbawi: Jurnal Ilmu Pendidikan, 16(1), 2020, pp. 11-21.

16. R.S. Damayanti, A. Suyatna, W. Warsono, U. Rosidin. Development of Authentic Assessment instruments for Critical Thinking skills in Global Warming with a Scientific Approach. International Journal of Science and Applied Science: Conference Series, 2(1), 2017, pp. 289.

17. E. Riadi. Statistika Penelitian (Analisis Manual dan IBM SPSS). Andi. 2015.

18. P.Y. Gu. Validation of an online questionnaire of vocabulary learning strategies for ESL learners. Studies in Second Language Learning and Teaching, 8(2 Special Issue), 2018, pp. 325-350.

19. S. Kumar, F. Martin, K. Budhrani, A. Ritzhaupt. Award-winning faculty online teaching practices: Elements of award-winning courses. Online Learning Journal, 23(4), 2019, pp. 160-180.

20. D. Chandra, R. Wilis, H. Frananda, L. Rahmi, D.A. Arif, B. Wijayanto, A. Putra. Pembuatan Peta Timbul Sebagai Media Pembelajaran Geografi [Making Embossed Maps as Learning Media for Geography] PEDAGOGIA: Jurnal Pendidikan, 8(2), 2019, pp 211-221

21. A. Putra. Penerapan Pembelajaran Kooperatif Model Group Investigation Pada Mata Pelajaran IPS Geografi. Laporan Penelitian Tindakan Kelas. Universitas Negeri Padang. 2010.

\section{AUTHORS PROFILE}

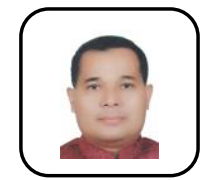

Dasril, is a Doctoral Student of Education administration, Universitas Negeri Padang Indonesia.

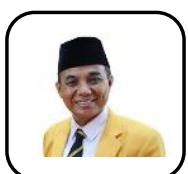

Rusdinal, is a Senior lecturers/professors of Education administration, Universitas Negeri Padang - Indonesia

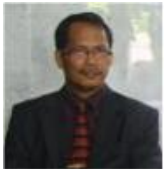

Yahya, is a Senior lecturers/professors of Education administration, Universitas Negeri Padang Indonesia

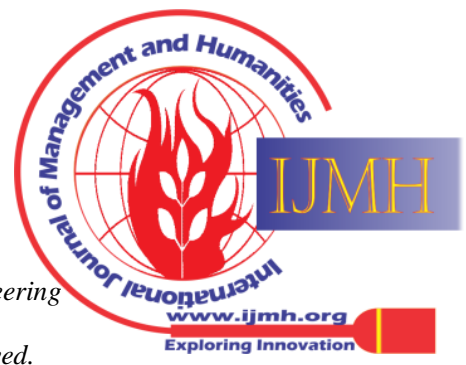

